\title{
EDITORIAL
}

\section{Mesenchymal stromal cells as treatment for chronic GVHD}

\author{
Bone Marrow Transplantation (2011) 46, 163-164; \\ doi:10.1038/bmt.2010.275
}

Chronic GVHD represents considerable morbidity and significant mortality after allogeneic hematopoietic stem cell transplantation (AHSCT). ${ }^{1,2}$

Treatment is far from satisfactory. Approximately $50 \%$ of patients respond to front-line therapy with steroids, with or without calcineurin inhibitors. ${ }^{3}$ Drawbacks of front-line treatment include the considerable side effects of chronic steroid use. Options for second-line treatment are extensive, suggesting low efficacy, and include azathioprine, low-dose TBI, thalidomide, mucophenolate mofetil, sirolimus, antiB-cell antibodies, extracorporeal photopheresis, imatinib and other immunosuppressive therapies. ${ }^{1,2,4,5}$ Progress is further confounded by uncertainty of diagnosis and the need for a consensus to measure response. ${ }^{6}$

Mesenchymal stromal cells (MSCs) have generated considerable interest in the management of acute GVHD based on the pioneering studies of the investigators at the Karolinska Institute. ${ }^{7-9}$ Phase II data in the management of steroid-resistant acute GVHD appear promising ${ }^{9}$ and a prospective controlled randomized trial is in progress in Europe. It is noteworthy that MSCs show efficacy in some experimental autoimmune disease models. ${ }^{10,11}$ Given that chronic GVHD resembles an autoimmune disorder in some respects, it is not surprising that anecdotal reports of MSCs to treat chronic GVHD are increasing. ${ }^{8,9,12}$ Moreover, MSCs have been used to manage tissue damage after AHSCT. ${ }^{13}$

Weng et al. ${ }^{14}$ report outcomes of 19 patients treated with MSCs for refractory chronic GVHD. The median dose of MSCs was $0.6 \times 10^{6}$ cells $/ \mathrm{kg}$ and 14 of 19 patients showed partial or complete responses $(74 \%)$. The overall response rate is similar to that reported for treatment of acute GVHD with MSCs. ${ }^{8} 9$ Immunosuppression given for chronic GVHD could be discontinued in five patients within a median of 324 days after cell infusion. In accordance with previous experience, there were no adverse events from the infusion of MSCs.

The response rates were graded according to the NIH scoring system. ${ }^{6}$ The cumulative response rate for skin was $78 \%$. Among three patients with scleroderma, one had a partial response. Cumulative responses in oral mucosa, liver and gastrointestinal tract were between 90 and $100 \%$. A patient with pulmonary involvement did not respond and died of invasive fungal infection. The 2-year survival rate was $78 \%$.

The results of the Weng study, although with small numbers of subjects, are promising and suggest that a prospective randomized trial to assess the role of MSCs in the management of chronic GVHD is now warranted. A reasonable approach would be to investigate outcomes in patients refractory to front-line therapy (as in the case in the current acute GVHD prospective trial with MSCs). Unfortunately, a number of unanswered questions pertaining to protocol design remain and include defining optimum cell dose, identifying the best source of MSCs, determining the optimum number of infusions, choosing autologous source vs the same allogeneic or a third party donor and establishing the most appropriate number of cell doublings for the MSC product.

The well-documented observation of reduced relapse in AHSCT recipients with chronic GVHD, suggests that ameliorating the condition may increase disease recurrence. Indeed, any treatment that decreases acute, and especially, chronic GVHD will also decrease the graft-versus-leukemia effect. ${ }^{15}$ One study does suggest that allotransplant recipients who received co-infusion of the allograft and MSCs had an increased probability of leukemic relapse. ${ }^{16}$ In this context, we argue in favour of the genetic modification of MSCs to incorporate a cell fate control gene that can enable the cells to be destroyed after administration of a pro-drug, as for example, the elimination of genetically modified MSCs expressing a mutant thymidylate kinase after ingestion of azidothymidine. ${ }^{17}$

A further advantage of a prospective trial for this condition is that it may help to more effectively uncover the immune modulating mechanisms of MSCs, which are confusing and may be highly dependent on the particular in vitro or in vivo model employed. Weng et al. found that after MSC infusions, there were significant changes in the proportion of $\mathrm{T}$ cells and $\mathrm{B}$ cells in responders vs nonresponders. At 3 months after MSC infusion, responders had significantly higher CD $4+$ and CD $8+$ cells. CD $8+$ CD28 + T-cells decreased when chronic GVHD improved and $\mathrm{CD} 5+\mathrm{CD} 19+\mathrm{B}$ cells increased in the responsive group. The proportion of $\mathrm{CD} 4+\mathrm{CD} 25+$ and $\mathrm{CD} 8+$ $\mathrm{CD} 25+$ cells did not change after MSC infusion. An increase in regulatory $\mathrm{CD} 25+$ cells has been proposed as one of the mechanisms for immune modulation by MSCs. ${ }^{18}$ Further studies in human subjects, especially with an appropriate control group, are likely to provide valuable insights into how MSCs affect immune function and will help to move this exciting field forward.

\section{Conflict of interest}

The authors declare no conflict of interest.

O Ringden ${ }^{1}$ and A Keating
${ }^{2}$
${ }^{1}$ Division of Clinical Immunology, Centre for Allogeneic
Stem Cell Transplantation, Karolinska Institutet, Karolinska
University Hospital Huddinge, Stockholm, Sweden and


${ }^{2}$ Cell Therapy Program, Princess Margaret Hospital, Ontaria Cancer Institute, Toronto, Ontario, Canada E-mail: armand.keating@uhn.on.ca

\section{References}

1 Ringden O, Deeg HJ. Clinical spectrum of graft-versus-host disease. In: Ferrara JLM, Deeg HJ, Burakoff S (eds). Graft vs Host Disease, 2nd edn. Marcel Dekker, Inc.: New York, 1996, pp 525-559.

2 Sullivan KM, Shulman HM, Storb R, Weiden PL, Witherspoon RP, McDonald GB et al. Chronic graft-versus-host disease in 52 patients: adverse natural course and successful treatment with combination immunosuppression. Blood 1981; 57: 267-276.

3 Weisdorf DJ. Chronic graft-versus-host disease: where is promise for the future? Leukemia 2005; 19: 1532-1535.

4 Flowers ME, Apperley JF, van Besien K, Elmaagacli A, Grigg $\mathrm{A}$, Reddy $\mathrm{V}$ et al. A multicenter prospective phase 2 randomized study of extracorporeal photopheresis for treatment of chronic graft-versus-host disease. Blood 2008; 112: 2667-2674.

5 Socie G, Devergie A, Cosset JM, Pierga JY, Esperou H, Girinski $\mathrm{T}$ et al. Low-dose (one gray) total-lymphoid irradiation for extensive, drug-resistant chronic graft-versus-host disease. Transplantation 1990; 49: 657-658.

6 Pavletic SZ, Martin P, Lee SJ, Mitchell S, Jacobsohn D, Cowen EW et al. Measuring therapeutic response in chronic graft-versus-host disease: National Institutes of Health Consensus Development Project on Criteria for Clinical Trials in Chronic Graft-versus-Host Disease: IV. Response Criteria Working Group report. Biol Blood Marrow Transplant 2006; 12: 252-266.

7 Le Blanc K, Rasmusson I, Sundberg B, Götherström C, Hassan M, Uzunel M et al. Treatment of severe acute graftversus-host disease with third party haploidentical mesenchymal stem cells. Lancet 2004; 363: 1439-1441.

8 Ringden O, Uzunel M, Rasmusson I, Remberger M, Sundberg B, Lönnies $\mathrm{H}$ et al. Mesenchymal stem cells for treatment of therapy-resistant graft-versus-host disease. Transplantation 2006; 81: 1390-1397.
9 Le Blanc K, Frassoni F, Ball L, Locatelli F, Roelofs H, Lewis I et al. Mesenchymal stem cells for treatment of steroidresistant, severe, acute graft-versus-host disease: a phase II study. Lancet 2008; 371: 1579-1586.

10 Parekkadan B, Tilles AW, Yarmush ML. Bone marrowderived mesenchymal stem cells ameliorate autoimmune enteropathy independently of regulatory T cells. Stem Cells 2008; 26: 1913-1919.

11 Sun L, Akiyama K, Zhang H, Yamaza T, Hou Y, Zhao S et al. Mesenchymal stem cell transplantation reverses multiorgan dysfunction in systemic lupus erythematosus mice and humans. Stem Cells 2009; 27: 1421-1432.

12 Zhou H, Guo M, Bian C, Sun Z, Yang Z, Zeng Y et al. Efficacy of bone marrow-derived mesenchymal stem cells in the treatment of sclerodermatous chronic graft-versus-host disease: clinical report. Biol Blood Marrow Transplant 2010; 16: 403-412.

13 Ringden O, Uzunel M, Sundberg B, Lönnies L, Nava S, Gustafsson $\mathbf{J}$ et al. Tissue repair using allogeneic mesenchymal stem cells for hemorrhagic cystitis, pneumomediastinum and perforated colon. Leukemia 2007; 21: 2271-2276.

14 Weng JY, Du X, Geng SX, Peng YW, Wang Z, Lu ZS et al. Mesenchymal stem cell as salvage treatment for refractory chronic GVHD. Bone Marrow Transplant 2010; 45: 1732-1740.

15 Ringden O, Karlsson H, Olsson R, Omazic B, Uhlin M. The allogeneic graft-versus-cancer effect. Br J Haematol 2009; 147: 614-633.

16 Ning H, Yang F, Jiang M, Hu L, Feng K, Zhang J et al. The correlation between cotransplantation of mesenchymal stem cells and higher recurrence rate in hematologic malignancy patients: outcome of a pilot clinical study. Leukemia 2008; 22: 593-599.

17 Neschadim A, McCart JA, Keating A, Medin JA. A roadmap to safe, efficient, and stable lentivirus-mediated gene therapy with hematopoietic cell transplantation. Biol Blood Marrow Transplant 2007; 13: 1407-1416.

18 Maccario R, Podesta M, Moretta A, Cometa A, Comoli P, Montagna $\mathrm{D}$ et al. Interaction of human mesenchymal stem cells with cells involved in alloantigen-specific immune response favors the differentiation of CD4 + T-cell subsets expressing a regulatory/suppressive phenotype. Haematologica 2005; 90: 516-525. 